\title{
Plasma cell leukemia with different expression of CD56 marker in the peripheral blood and bone marrow: A case report
}

\section{Introduction}

Plasma cell leukemia (PCL) is a rare and aggressive entity of malignant plasma cell proliferation that corresponds to $2-4 \%$ of plasma cell myeloma (PCM) cases. ${ }^{1,2}$ According to the World Health Organization (WHO), PCL is defined as a disorder in which clonal plasma cells constitute more than $20 \%$ of total leukocytes in the blood or their absolute count is more than $2.0 \times 10^{9} / \mathrm{L} \cdot{ }^{1,3}$ The bone marrow is usually extensively and diffusely infiltrated. Neoplastic plasma cells are frequently present in extra-medullary sites such as the liver, spleen, body cavity effusions, and spinal fluid.PCL can be classified into: primary (de novo, $60-70 \%$ of all PCLs) or secondary which is a leukemic transformation occurring in approximately $1 \%$ of previously diagnosed PCMs. ${ }^{4}$ Patients with PCL have aggressive disease, poor response to therapy, and a relatively short survival. ${ }^{1}$

\section{Case report}

A 62-years-old female patient presented to the Hematology department at Alexandria main university hospital suffering from bone pain, fever,and dysuria. Past history and family history were irrelevant. On examination, chest and heart were free and there was no organomegaly (lymphadenopathy, hepatomegaly or splenomegaly). On laboratory evaluation, the complete blood picture revealed a hemoglobin level of $8.3 \mathrm{~g} / \mathrm{dL}$, hematocrit of $25.2 \%$, white blood cell count of $19.51 \times 10^{9} / \mathrm{L}$ and platelet count of $114 \times 10^{9} / \mathrm{L}$. Morphological examination of peripheral blood smear showed small to medium-sized a typical lymphoplasmacytoid cells (accounting for $85 \%$ of the differential WBCs count) with eccentric nuclei and basophilic cytoplasm,(Figure 1A). Bone marrow aspirate examination revealed that $47 \%$ of total nucleated marrow cells were atypical lymphoplasmacytoid cells with a morphology similar to those in the peripheral blood (Figure 1B), and 13\% were lymphocytes. Granulocytic, erythroid and megakaryocytic lineages were depressed.

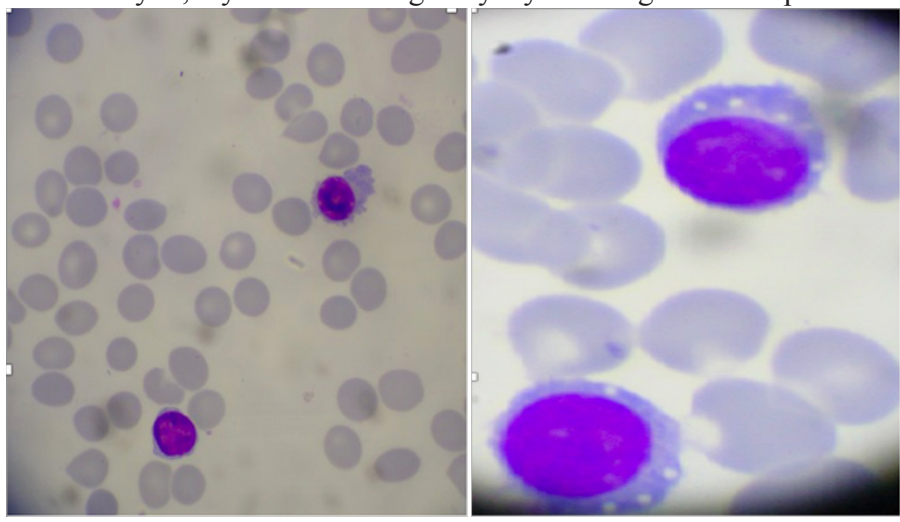

Figure I (A) PB smear showing small to medium-sized lymphoplasmacytoid cells with eccentric nucleus and basophilic cytoplasm. (B) BM aspirate showing atypical lymphoplasmacytoid cells with basophilic cytoplasm.
Volume 8 Issue 2 - 2020

\author{
Akram Deghady, Nahla Farahat, Abeer \\ Elhadidy, Hanaa Donia, Hadeer Rashid \\ Department of Clinical Pathology,Faculty of Medicine,University \\ of Alexandria, Egypt
}

Correspondence: Akram Deghady, Department of Clinical Pathology,Faculty of Medicine,University of Alexandria, Egypt, Emailakram6ı@yahoo.com

Received: January 03, 2020 | Published: April 24, 2020

Other laboratory tests showed total serum proteins of $6.2 \mathrm{~g} / \mathrm{dL}$, albumin of $3.4 \mathrm{~g} / \mathrm{dL}$ and a monoclonal band of $\operatorname{IgG}$, (lambda) by immunofixation $(1.7 \mathrm{~g} / \mathrm{dL})$. Total serum Calcium was normal $(7.9 \mathrm{mg} /$ $\mathrm{dL})$, and renal functions were abnormal with increased blood urea (86 $\mathrm{mg} / \mathrm{dL})$ and serum creatinine $(2 \mathrm{mg} / \mathrm{dL})$.

Flowcytometeic immunophenotyoing of the bone marrow revealed the presence of clonal plasma cells expressing CD138, CD38, CD56 and Cytoplasmic lambda lightchain and negative for CD19 and Cytoplasmic kappa light chain, reflecting a plasma cell malignancy despite the morphologic features of lymphoplasmacyticlymphoma(Figure 2). Additionally, immunophenotyping of the peripheral blood was also performed and revealed the presence of clonal plasma cells with the same immunophenotype as the previously identified plasma cells from the bone marrow except that they were CD56 negative(Figure $3)$. Based on the previous findings, the final diagnosis of the patient was released as plasma cell leukemia.

\section{Discussion}

PCL is a rare disease with median patient age younger than myeloma at diagnosis. The bone marrow is usually extensively infiltrated which leads to bone marrow suppression and high incidence of anemia and thrombocytopenia. ${ }^{2,5,6}$ Neoplastic plasma cells are frequently found in extramedullary sites such as the liver, spleen, body cavity effusions, and spinal fluid. ${ }^{1}$ This appears to be the result of a lower expression of cell adhesion molecules, such as CD56, facilitating the release of leukemic plasma cells from the BM microenvironment. ${ }^{5,7}$

Our patient had no extramedullary involvement at diagnosis, but she presented with anemia, bone pains and renal affection. Her PB and BM aspirate showed extensive infiltration by lymphoplasmacytoid cells that had similar morphology, which made the differential diagnosis between lymphoplasmacytic lymphoma (LPL) and PCL difficult by morphological analysis alone. Normal plasma cells are $\mathrm{CD} 19^{+} / \mathrm{CD} 45^{+} / \mathrm{CD} 38^{\text {bright }} / \mathrm{CD} 56^{-}$while neoplastic plasma cells are usually $\mathrm{CD} 19^{-} / \mathrm{CD} 45^{-} / \mathrm{CD} 38^{+} / \mathrm{CD} 56^{+} \cdot{ }^{7,8}$ However, in this case plasma 
cells in $\mathrm{BM}$ areCD56 positive, while in $\mathrm{PB}$ are $\mathrm{CD} 56$ negative.CD56 mediates cell-cell and cell-matrix interactions. So, loss of CD56 expression could accelerate the process of metastatic spread. ${ }^{9,10}$ The regulation of CD56 is controlled by a very precise mechanism. CD56 can be downregulated during migratory events and re-expressed when the cell reaches a specific site or organ. ${ }^{7}$ This finding is also in accordance with study by Pellat-Deceunynck et al, ${ }^{7}$ who found migrated plasma cells in the peritoneal cavity of multiple myeloma patients. Cells localized in the peritoneal cavity expressed CD56 and have high proliferation activity.
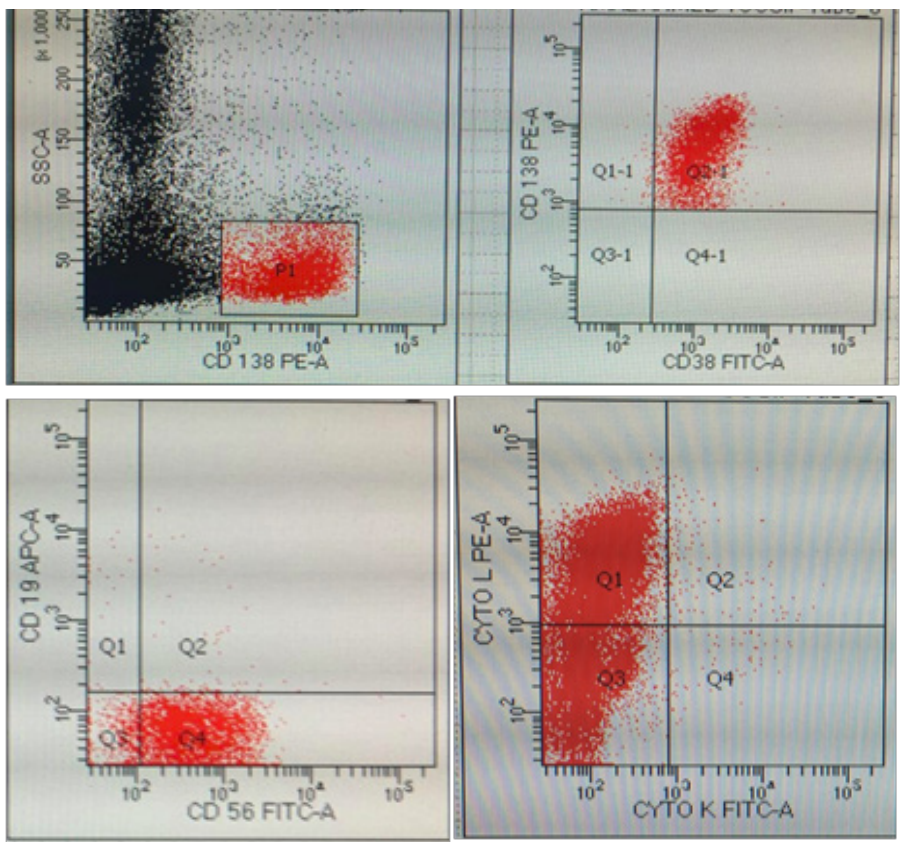

Figure 2 Flow cytometeic immunophenotyoing of the BM showing lambda restricted clonal plasma cells that are CD56 positive.

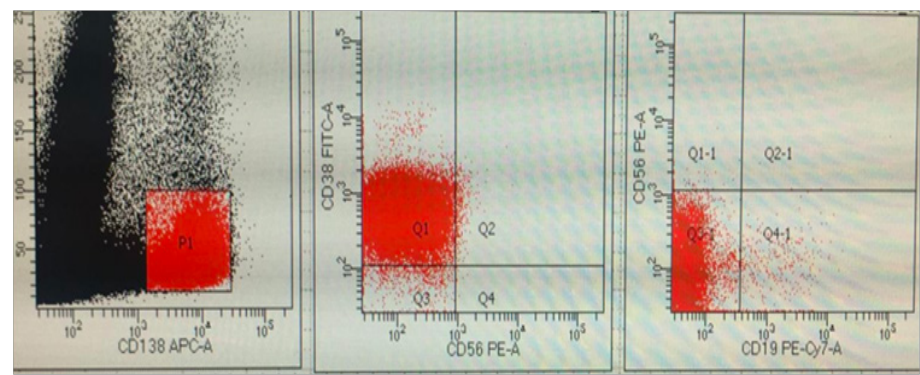

Figure 3 Flow cytometeic immunophenotyoing of the PB showing lambda restricted clonal plasma cells that are CD56 negative.

\section{Acknowledgments}

None.

\section{Conflicts of interest}

The author declares no conflict of interest.

\section{References}

1. Swerdlow SH CE, Harris NL, Jaffe ES, et al. WHO Classification of Tumours of Haematopoietic and Lymphoid Tissues. Revised 4th ed. Lyon.WHO press,2017.

2. Fernández de Larrea C, Kyle RA, Durie BG, et al. Plasma cell leukemia: consensus statement on diagnostic requirements, response criteria and treatment recommendations by the International Myeloma Working Group. Leukemia. 2013;27(4):780-791.

3. International Myeloma Working Group. Criteria for the classification of monoclonal gammopathies, multiple myeloma and related disorders: a report of the International Myeloma Working Group. Br J Haematol. 2003;121(5):749-757.

4. Gonsalves W, Rajkumar SV, Go RS, et al. Trends in survival of patients with primary plasma cell leukemia: a population-based analysis. Blood.2014;124(6):907-912.

5. García-Sanz R, Orfao A, González M, et al. Primary plasma cell leukemia: clinical, immunophenotypic, DNA ploidy, and cytogenetic characteristics. Blood. 1999;93(3):1032-1037.

6. Fonseca R, Blood EA, Oken MM, et al. Myeloma and the $t(11 ; 14)$ (q13;q32); evidence for a biologically defined unique subset of patients. Blood. 2002;99(10):3735-3741.

7. Raja KR, Kovarova L, Hajek R. Review of phenotypic markers used in flow cytometric analysis of MGUS and MM, and applicability of flow cytometry in other plasma cell disorders. $\mathrm{Br} \mathrm{J}$ Haematol. 2010;149(3):334-351

8. Bataille R, Jégo G, Robillard N, Barillé-Nion S, et al. The phenotype of normal, reactive and malignant plasma cells. Identification of many and multiple myelomas and of new targets for myeloma therapy. Haematologica. 2006;91(9):1234-1240.

9. Blaheta, RA, Hundemer M, Mayer, G, et al. Expression level of neural cell adhesion molecule (NCAM) inversely correlates with the ability of neuroblastoma cells to adhere to endothelium in vitro. Cell Communication and Adhesion.2002;9(3):131-147.

10. Blaheta RA, Beecken WD, Engl T, et al. Human cytomegalovirus infection of tumor cells downregulates NCAM (CD56): a novel mechanism for virus-induced tumor invasiveness. Neoplasia. 2004;6:323-331. 